\title{
上位頚椎発生春髄腫瘍の手術成績と治療上の問題点
}

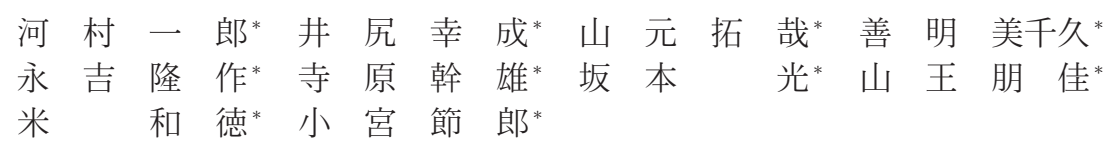

\section{Problems and Clinical Course after Operation of Spinal Cord Tumor at Upper Cervical Spine}

Ichiro Kawamura*, Kosei Ijiri*, Takuya Yamamoto*, Michihisa Zenmyo*, Ryusaku Nagayoshi*, Mikio Terahara*, Hikaru Sakamoto*, Tomoka Sanno*, Kazunori Yone*, and Setsuro Komiya*

上位頚椎は砂時計腫の好発部位であり，春髄腫瘍は上位頚椎レベルに比較的多く発生が認められる，当 院で行った上位頝椎発生脊䯣腫瘍の治療成績を retrospective に検討した。1 988 年から 2009 年までに当 科で手術した脊䯣腫瘍 203 例中，C1/2 レベルでの発生例 14 例を対象とした。臨床成績は良好であったが， 術後小脳出血を 1 例認めた。 また $\mathrm{C} 2$ 椎弓温存した群に対し， C2 椎弓切除群で術後後彎変形を呈する傾 向にあった．C2 の束突起温存は術後後彎変形を防止するために考慮すべきである．また周術期合併症む 頻度は低いものの重篤なあのがあり, 特に脳出血に関しては多量の脳脊髄液損失が原因の可能性も示唆さ れているため, 術後頭部 CT 撮影等周術期には厳重な管理が必要之考えられる。

Fourteen patients with upper cervical spinal cord tumor were followed up in order to investigate the clinical course after operation and problems including postoperative complications. The symptoms were improved after the surgery in nine out of 14 patients.

Two cases deteriorated after operation, due to cerebellar hemorrhage and due to hyperemia of the spinal cord after acute decompression. The patient with cerebellar hemorrhage case went into a coma approximately six hours after surgery. As cerebellar hemorrhage may occur because of CSF leakage during and after operation, we recommended rigorous checking of the head by CT after surgery for spinal cord tumors at the upper cervical spine.

Key words : spinal cord tumor (春䯣腫瘍), upper cervical spine (上位䅡椎), postoperative complication（合併症）, cerebellar hemorrhage（脳出血）

\section{は じめに}

上位頝椎レベルの脊髄腫瘍は比較的多く認められる が，その解剖学的特殊性から治療に難渋する点が多い. 今回上位䅡椎レベルから発生した脊䯣腫瘍の手術成績, 合併症を retrospective に調査し，その問題点を検討 した.

\section{対象および方法}

対象は 1988 年より当科で手術を行った春䯣腫瘍 203 例中，C1-2 レベル発生であった 14 例を対象とし た。手術時平均年齢は 53.1 歳 $(29-77$ 歳), 性別は 男性 8 例, 女性 6 例, 腫瘍局在部位は硬膜内䯣外 12 例, 䯣内 2 例, 組織学的診断は神経鞘腫 11 例, 䯣膜 腫 1 例, 神経線維腫 1 例, 上衣腫 1 例であった。

以上の症例より, Cooper-Epstein grade を用いた

\footnotetext{
* 鹿児島大学大学院医歯学総合研究科運動機能修復学講座整形外科学 Department of Orthopaedic Surgery, Kagoshima Graduate School of Medical and Dental Science, Kagoshima, Japan
} 


\section{平均術後経過: 35ヶ月 (4-96ヶ月)}

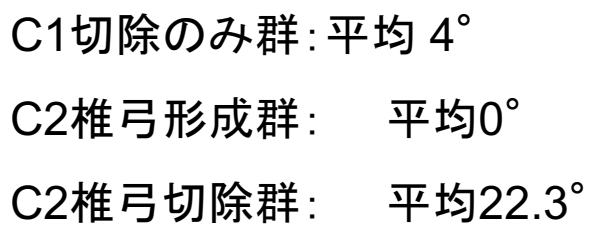

術後後弯変形の進行

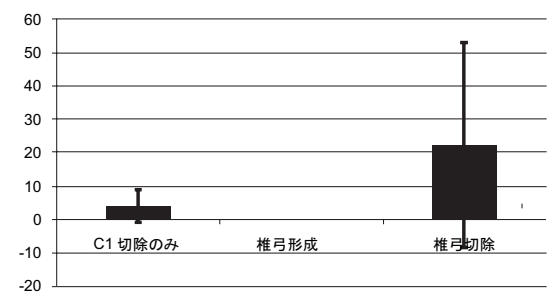

\section{椎弓切除群に術後後弯変形の傾向はあったが有意差は認めなかった}

Fig.1 術後頝椎後弯の進行 $(\mathrm{C} 2-7)$

臨床成績 周術期合併症, 腫瘍全摘の可否と再発の有 無, C2-7 の術後後彎変形（curvature of the cervical column）の関連を検討した.

結果

臨床成績：Cooper-Epstein grade で 1 grade 以上改 善した症例は 9 例，不変は 3 例であった。悪化した症 例を 2 例認め，そのうち 1 例は脳出血による合併症に よるむのであり 1 例は髄内腫瘍であった。

腫瘍全的の可否・再発：全症例中全摘が 11 例，亜全 摘が 3 例（全例：神経症腫，Dumbbell type）であっ た。再発症例はなく，亜全摘の症例屯残存腫瘍の増大 は認めなかった。

術式・術後後彎変形：平均手術時間は 287 分，出血量 は $418 \mathrm{~g}$ であった。術式は $\mathrm{C} 1$ 後弓切除のみが 7 例, $\mathrm{C} 2$ 椎弓形成のみが 3 例, $\mathrm{C} 1$ 切除 $+\mathrm{C} 2$ 椎弓形成が 1 例， $\mathrm{C} 1+\mathrm{C} 2$ と屯に椎弓切除が 3 例であった。術後の 攧椎後弯変形の進行は, 平均 $12.2^{\circ}$ であった。

$\mathrm{C} 1$ 切除のみは平均 $4^{\circ}$ 後弯, $\mathrm{C} 2$ 椎弓形成を行った群 は後弯の進行なく, C2 椎弓切除を行った群では平均 $22^{\circ}$ 後弯变形を認めたが，各群に有意差はなかった (Fig.1).

合併症：小脳出血を 1 例, 術後症状悪化例 1 例, 局所 感染を 1 例，䯣液漏を 2 例認めた。

症状悪化例の 1 例は軟膜下上衣下腫であった。

症例提示：術後小脳出血例（Fig.2）
55 歳 男性 C1-2 硬膜内䯣外腫瘍 Asazuma type III b （神経鞘腫）に対し，腫瘍全摘術施行.

病棟帰室 6 時間後より不穏，意識レベルの低下認め, 頭部 CT 施行したところ，小脳出血，右側頭葉の出血 を認めた。明らかな動脈性の出血源はなく、びまん性 の出血であり, 静脈洞の破綻による出血が疑われたが, 詳細な原因は不明であった。

考察

合併症：春䯣腫瘍術後の脳出血は過去にも報告 ${ }^{4) 8}$ () は されており，脳脊髄液の極度の減少や腫瘍切除による third space の出現 ${ }^{377) 8>9)}$, また体位, 脱水, 術中血 圧が関係するとの説 ${ }^{13)}$ がある。しかしその症例も多 くはなく，いまだそのメカニズムは明らかではない. そのため長時間手術，広範囲に硬膜切開を行う症例は 術後頭部 CT を行って打り, 本症例以降, 術後に頭部 CT をルーチンに行っているが，脳出血をきたした症 例は認めていない。

脊柱变形: 今回の調查でも $\mathrm{C} 2$ 椎弓切除した症例に後 弯変形を認める傾向にあった。過去の報告でも同様の 報告 ${ }^{25}$ 5) あり，また椎弓形成で屯後弯変形をきたすと 報告 ${ }^{6)}$ されている。そこで $\mathrm{C} 2$ レベルの展開が必要な 症例は傍脊柱筋を付着させたまま, 拡大し, 後方要素 をなるべく温存することを試みており，今度これらが 後弯变形に影響を及ぼすかを検討している。 

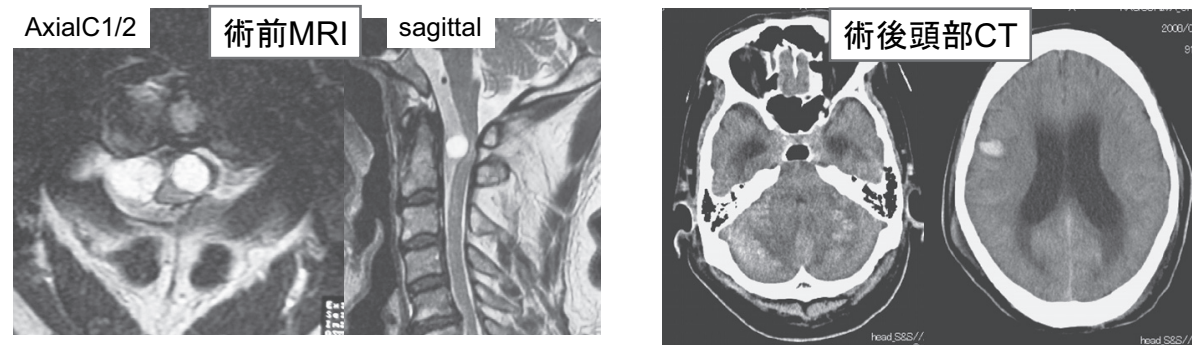

\section{C1-2 IDEM (Asazuma type IIIb)に対し、腫瘍全摘術施行 術後小脳出血、右側頭葉出血を認めた 明らかな出血源認めず、静脈洞の破綻による出血が疑われたが、 詳細な原因は不明}

Fig.2 術後脳出血症例

ま と め

○上位頚椎レベルに発生した脊髄腫瘍における手術成 績と問題点を検討した

・臨床成績は比較的良好であった

○重篤な合併症があり，周術期の厳重な管理が必要

参 考 文 献

1）青山真樹ら：脊䯣腫瘍術後に判明した多発性静脈性脳 出血の一例。日本集中治療医学会雑誌，12：277, 2005.

2) Fassett, D. R., et al.: Cervical spine deformity associated with resection of spinal cord tumor. Neurosurg. Focus, 20 : E2, 2006.

3) Hashidate, H., et al.: Cerebellar hemorrhage after spine surgery. J. Orthop. Sci., 13 : 150-154, 2008.
4）岩波明生ら：上位頚椎部硬膜内䯣外腫瘍の手術治療成 績之予後一神経鞘腫之髄膜腫について一。 日脊椎脊䯣病 会誌, 17(1)：645, 2006.

5) Katsumi, Y., et al.: Analysis of cervical instability resulting from laminectomies for removal of spinal cord tumor. Spine, 14 : 1171-1177, 1989.

6) Ratliff, J.K., Cooper, P.R.: Cervical laminoplasty: a critical review. J. Neurosurg., 98 : 230-238, 2003.

7) Sakaura, H., et al.: Multiple cerebellar hemorrhagic infarctions following surgery for a huge atlantoaxial neurinoma. Spine J., 6 : 86-89, 2006.

8) Siu, T.L., et al.: Cerebellar hemorrhage following supratentorial craniotomy. J. Clin. Neurosci., 10(3) : 378-384, 2003

9) Thomas, G., et al.: Supratentorial and infratentorial intraparenchymal hemorrhage secondary to intracranial CSF hypotension following spinal surgery. Spine, 27(18) : 410-412, 2002. 